\title{
Cluster Headache is Still Lurking in the Shadows
}

\author{
Paolo Martelletti (i) $\cdot$ Martina Curto
}

Received: May 10, 2021 / Accepted: May 27, 2021 / Published online: June 6, 2021

(C) The Author(s) 2021

\begin{abstract}
Cluster headache, apart from its legendary reputation as the most violent headache that can exist, suffers from an average 60-month delay in diagnosis. The simplicity of the clinical manifestations, although dramatic, makes this delay inexplicable. The education of emergency department physicians and various specialists not specifically dedicated to headaches allows cluster headache to remain in a lurking position with flourishing periods of disease that are often unpredictable in both onset and disappearance.
\end{abstract}

P. Martelletti $(\bowtie) \cdot$ M. Curto

Department of Clinical and Molecular Medicine,

Sapienza University, Rome, Italy

e-mail: paolo.martelletti@uniroma1.it

P. Martelletti

Regional Referral Headache Centre, Sant'Andrea

University Hospital, Rome, Italy

M. Curto

International Consortium for Mood Psychotic and Mood Disorders Research, McLean Hospital,

Belmont, MA, USA

M. Curto

Department of Mental Health, ASL Roma 3, Centro

di Salute Mentale XI Municipio, Rome, Italy
Older drugs have always shown high efficacy but also an equally high rate of adverse events, often discouraging their appropriate use. The availability of a new drug class such as monoclonal antibodies for calcitonin gene-related peptide or its receptor $\left(\mathrm{CGRP}_{(\mathrm{r})}\right)$, which have already been efficient for migraine, shows a jeopardized geography of access in the world, and this favors the progression of the episodic form into chronic and of the chronic into refractory.

Keywords: Calcitonin gene-related peptide; Cluster headache; Education; Galcanezumab; Refractory chronic cluster headache; Verapamil 


\section{Key Summary Points}

Cluster headache is a quasi-rare disorder affecting 1 in 500 of the general population and still represents an unresolved challenge today.

The pathogenesis of cluster headache is currently based on the derangement of the interactions existing between the trigeminovascular leading to the release of specific neuropeptides like calcitonin gene-related peptides (CGRP) and pituitary adenylate cyclase-activating polypeptide 38 (PACAP-38).

The treatment of cluster headache acute attacks still revolves around drug aged 30 years like subcutaneous sumatriptan.

The preventive treatment of cluster headache is based on the availability of galcanezumab, but this option is geographically limited to the US.

In those countries where galcanezumab is not available, verapamil at high dosage is still used with success but its use is limited by its cardiovascular risks.

The social and economic burden of this disease is high, therefore it is important to spread the use of CGRP monoclonal antibodies for all patients everywhere.

\section{DIGITAL FEATURES}

This article is published with digital features, including a summary slide, to facilitate understanding of the article. To view digital features for this article go to https://doi.org/10.6084/ m9.figshare.14687217.

\section{CLUSTER HEADACHE, THE CINDERELLA AMONG THE PRIMARY HEADACHES}

Despite all the remarkable efforts to raise awareness of cluster headache $(\mathrm{CH})$, it still represents an unresolved challenge today, penalizing this scant group of patients that shows a prevalence of 1 in 500 of the general population, an inheritance that presents a risk from 5 to 18 times for first-degree relatives and from 1 to 3 for second-degree relatives of having the same pathology [1], with family history rate calculated at $6.27 \%$ [2]. The simplicity of its clinical profile is contrasted by the fact that the diagnosis is made with an average delay of 5 years from the first appearance of the attacks, and the correct therapeutic approach is administered only to a minority of these patients [3]. As a natural consequence of these discrepancies in health care, this population of $\mathrm{CH}$ patients shows a high ratio of sickness absence benefits and greater access to disability pensions [4].

The pathogenesis of this disease is, at the current state of knowledge, based on the derangement of the complex interactions existing between the trigeminovascular system activating the trigeminal-autonomic reflex, leading to the release of specific neuropeptides like calcitonin gene-related peptides (CGRP) and pituitary adenylate cyclase-activating polypeptide 38 (PACAP-38), and its interactions with a deranged (putative) hypothalamic control center $[5,6]$. Further multiple basic and clinical research approaches have added important information on the role of neurosteroids, neuroimaging and neurophysiology data, sleep disorders, and psychiatric comorbidities in this still not completely clear pathophysiological picture of $\mathrm{CH}$ [7-10].

One of the well-known criticalities in the treatment of $\mathrm{CH}$ is the aged drugs used for the control of the brutal attacks and for the suppression of the active and thriving phases of the disease or its prevention [11, 12]. However, the lightning-fast speed of the activation phases, with crises that reach the maximum in intensity and daily frequency in $24-72 \mathrm{~h}$, requires a fasttrack assistance path from the emergency 
department to the hospital structures and the specialists dedicated to it, in order to prevent the disease from reaching its highest clinical expression and therefore a possible delayed response to therapy [13-15].

Beyond this criticality, it has recently been highlighted that the transition from randomized control trials (RCTs), which offer a mathematical view of drugs applied to a specific pathology, should be weighed against the flexibility of clinical practice as observed by realworld evidence (RWE) data [16]. The sum of all these criticalities has in fact brought to the clinical researchers' attention the entity of refractory chronic cluster headache $(\mathrm{RCCH})$ [17], which will hopefully find a place in the next revision of the International Classification of Headache Disorders, the 4th.

The paucity of therapeutic approaches towards $\mathrm{CH}$ has over time stimulated researchers to reapply innovative therapies already used in migraine, such as neurostimulation and botulinum toxin with RWE, unfortunately far from the original results of the RCTs $[18,19]$.

\section{OLD AND NOVEL TREATMENTS FOR CH}

Acute treatment of $\mathrm{CH}$ is based on subcutaneous sumatriptan and oxygen, the transitional treatment on the use of corticosteroids, and the preventative one on the use of verapamil [5]: this pharmacological approach is more than 30 years old.

Unfortunately, the problems for $\mathrm{CH}$ do not end here because only part of these suffering patients can take advantage of a new therapy that has been extended from migraine also to $\mathrm{CH}$ in the USA and immediately abates the crises. In fact, on February 28, 2020, the European Medicines Agency (EMA) rejected the approval of galcanezumab (100 $\mathrm{mg} \times 3 /$ monthly subcutaneously) for the prevention of episodic and chronic cluster headache, a highly effective therapy currently available in USA after the Food Drug and Administration approval [20-23]. There is hope today for a reassessment by EMA after the publication of ongoing studies on RWE.
Meanwhile, given the dramatic nature of the clinical picture and the extreme violence of the painful attacks, scientific journals continue to dedicate little space to $\mathrm{CH}$, not only because of its relative rarity, but especially because the medical world has a lack of knowledge on $\mathrm{CH}$.

Just to give an example, among the currently available preventative therapies, verapamil at high dosage $(360 \mathrm{mg}$ and more up to $720 \mathrm{mg} /$ day) offers good efficacy [24]. Unfortunately, a possible adverse event an occur as the atrioventricular block produces an underdosage in clinical practice with a lack of efficacy.

Last but not least, recent valuable estimates of the direct and indirect costs of episodic and chronic $\mathrm{CH}$ in the specific setting of a tertiary headache center confirmed the high economic impact of $\mathrm{CH}$ on both the National Health System and patients [25].

Therefore, we must reiterate the strong need for extended clinical-diagnostic points for $\mathrm{CH}$ jointly to a better education to pharmacological management, in order to improve the status of this neglected patients' population [26].

\section{ACKNOWLEDGEMENTS}

Funding. No funding or sponsorship was received for this study or publication of this article.

Authorship. All named authors meet the International Committee of Medical Journal Editors (ICMJE) criteria for authorship for this article, take responsibility for the integrity of the work as a whole, and have given their approval for this version to be published.

Authors' Contributions. PM and MC contributed equally to the writing of this commentary.

Disclosures. The authors report no conflicts of interest related to the content of this commentary. Paolo Martelletti is a member of the journal's Editorial Board. 
Compliance with Ethics Guidelines. This article is based on previously conducted studies and does not contain any new studies with human participants or animals performed by any of the authors.

Open Access. This article is licensed under a Creative Commons Attribution-NonCommercial 4.0 International License, which permits any non-commercial use, sharing, adaptation, distribution and reproduction in any medium or format, as long as you give appropriate credit to the original author(s) and the source, provide a link to the Creative Commons licence, and indicate if changes were made. The images or other third party material in this article are included in the article's Creative Commons licence, unless indicated otherwise in a credit line to the material. If material is not included in the article's Creative Commons licence and your intended use is not permitted by statutory regulation or exceeds the permitted use, you will need to obtain permission directly from the copyright holder. To view a copy of this licence, visit http://creativecommons.org/licenses/by$\mathrm{nc} / 4.0 /$.

\section{REFERENCES}

1. Russell MB. Epidemiology and genetics of cluster headache. Lancet Neurol. 2004;3(5):279-83. https://doi.org/10.1016/S1474-4422(04)00735-5.

2. O'Connor E, Simpson BS, Houlden H, Vandrovcova J, Matharu M. Prevalence of familial cluster headache: a systematic review and meta-analysis. J Headache Pain. 2020;21(1):37. https://doi.org/10. 1186/s10194-020-01101-w.

3. Lambru G, Andreou AP, de la Torre ER, Martelletti P. Tackling the perils of unawareness: the cluster headache case. J Headache Pain. 2017;18(1):49. https://doi.org/10.1186/s10194-017-0757-7.

4. Sjöstrand C, Alexanderson K, Josefsson P, Steinberg A. Sickness absence and disability pension days in patients with cluster headache and matched references. Neurology. 2020;94(21):e2213-21. https:// doi.org/10.1212/WNL.0000000000009016.

5. Wei DY, Goadsby PJ. Cluster headache pathophysiology-insights from current and emerging treatments. Nat Rev Neurol. 2021. https://doi.org/ 10.1038/s41582-021-00477-w.

6. Ashina M, Martelletti P. Pituitary adenylate-cyclaseactivating polypeptide (PACAP): another novel target for treatment of primary headaches? J Headache Pain. 2018;19:33. https://doi.org/10. 1186/s10194-018-0860-4.

7. Koverech A, Cicione C, Lionetto L, Maestri M, Passariello F, Sabbatini E, Capi M, De Marco CM, Guglielmetti M, Negro A, Di Menna L, Simmaco M, Nicoletti F, Martelletti P. Migraine and cluster headache show impaired neurosteroids patterns. J Headache Pain. 2019;20(1):61. https://doi.org/10. 1186/s10194-019-1005-0.

8. Vollesen AL, Benemei S, Cortese F, LabastidaRamírez A, Marchese F, Pellesi L, Romoli M, Ashina M, Lampl C. School of advanced studies of the European Headache Federation (EHF-SAS). Migraine and cluster headache-the common link. J Headache Pain. 2018;19(1):89. https://doi.org/10. 1186/s10194-018-0909-4.

9. Barloese M. Current understanding of the chronobiology of cluster headache and the role of sleep in its management. Nat Sci Sleep. 2021;13:153-62. https://doi.org/10.2147/NSS.S278088 (eCollection 2021).

10. Kim BS, Chung PW, Kim BK, Lee MJ, Park JW, Chu MK, Ahn JY, Bae DW, Song TJ, Sohn JH, Oh K, Kim D, Kim JM, Kim SK, Choi YJ, Chung JM, Moon HS, Chung CS, Park KY, Cho SJ. The impact of remission and coexisting migraine on anxiety and depression in cluster headache. J Headache Pain. 2020;21(1):58. https://doi.org/10.1186/s10194-02001120-7.

11. Steiner TJ, Jensen R, Katsarava Z, Linde $M$, MacGregor EA, Osipova V, Paemeleire K, Olesen J, Peters M, Martelletti P. Aids to management of headache disorders in primary care (2nd edition): on behalf of the European Headache Federation and Lifting The Burden: the Global Campaign against Headache. J Headache Pain. 2019;20(1):57. https:// doi.org/10.1186/s10194-018-0899-2.

12. de Andrés F, Lionetto L, Curto M, Capi M, Cipolla F, Negro A, Martelletti P. Acute, transitional and longterm cluster headache treatment: pharmacokinetic issues. Expert Opin Drug Metab Toxicol. 2016;12(9):1011-20. https://doi.org/10.1080/ 17425255.2016.1201067.

13. Negro A, Spuntarelli V, Sciattella P, Martelletti P. Rapid referral for headache management from emergency department to headache centre: four years data. J Headache Pain. 2020;21(1):25. https:// doi.org/10.1186/s10194-020-01094-6. 
14. Luciani M, Negro A, Spuntarelli V, Bentivegna E, Martelletti P. Evaluating and managing severe headache in the emergency department. Expert Rev Neurother. 2021;21(3):277-85. https://doi.org/10. $1080 / 14737175.2021 .1863148$.

15. Giamberardino MA, Affaitati G, Costantini R, Guglielmetti M, Martelletti P. Acute headache management in emergency department A narrative review. Intern Emerg Med. 2020;15(1): 109-17. https://doi.org/10.1007/s11739-019-02 266-2.

16. Martelletti P, Curto M. Headache: cluster headache treatment-RCTs versus real-world evidence. Nat Rev Neurol. 2016;12(10):557-8. https://doi.org/10. 1038/nrneurol.2016.134.

17. Mitsikostas DD, Edvinsson L, Jensen RH, Katsarava Z, Lampl C, Negro A, Osipova V, Paemeleire K, Siva A, Valade D, Martelletti P. Refractory chronic cluster headache: a consensus statement on clinical definition from the European Headache Federation. J Headache Pain. 2014;15(1):79. https://doi.org/10. $1186 / 1129-2377-15-79$

18. Martelletti $\mathrm{P}$, Jensen $\mathrm{RH}$, Antal A, Arcioni R, Brighina $F$, de Tommaso $M$, Franzini A, Fontaine $D$, Heiland $M$, Jürgens $T P$, Leone $M$, Magis $D$, Paemeleire K, Palmisani S, Paulus W, May A. European Headache Federation. Neuromodulation of chronic headaches: position statement from the European Headache Federation. J Headache Pain. 2013;14(1):86. https://doi.org/10.1186/1129-237714-86.

19. Lampl C, Rudolph M, Bräutigam E. OnabotulinumtoxinA in the treatment of refractory chronic cluster headache. J Headache Pain. 2018;19(1):45. https://doi.org/10.1186/s10194-0180874-y.
20. https://www.ema.europa.eu/en/documents/smop/ questions-answers-refusal-change-marketingauthorisation-emgality-galcanezumab_en.pdf viewed May 2, 2021.

21. Argyriou AA, Vikelis M, Mantovani E, Litsardopoulos P, Tamburin S. Recently available and emerging therapeutic strategies for the acute and prophylactic management of cluster headache: a systematic review and expert opinion. Expert Rev Neurother. 2021;21(2):235-48. https://doi.org/10. $1080 / 14737175.2021 .1857240$.

22. Mudugal D, Monteith TS. Drug profile: galcanezumab for prevention of cluster headache. Expert Rev Neurother. 2021;21(2):145-55. https:// doi.org/10.1080/14737175.2021.1852931.

23. Ossipov MH, Raffa RB, Pergolizzi JV. Galcanezumab: a humanized monoclonal antibody for the prevention of migraine and cluster headache. Drugs Today (Barc). 2020;56(1):5-19. https://doi. org/10.1358/dot.2020.56.1.3069863.

24. Alexandre J, Humbert $X$, Sassier M, Milliez P, Coquerel A, Fedrizzi S. High-dose verapamil in episodic and chronic cluster headaches and cardiac adverse events: Is it as safe as we think? Drug Saf Case Rep. 2015;2(1):13. https://doi.org/10.1007/ s40800-015-0015-3.

25. Negro A, Sciattella P, Spuntarelli V, Martelletti P, Mennini FS. Direct and indirect costs of cluster headache: a prospective analysis in a tertiary level headache centre. J Headache Pain. 2020;21(1):44. https://doi.org/10.1186/s10194-020-01115-4.

26. Martelletti P. Cluster headache management and beyond. Expert Opin Pharmacother. 2015;16(10): 1411-5. https://doi.org/10.1517/14656566.2015. 1052741 . 